\title{
Was Kuznets Right? New Evidence on the Relationship between Structural Transformation and Inequality
}

DOI:

10.1080/00220388.2019.1702161

\section{Document Version}

Final published version

Link to publication record in Manchester Research Explorer

\section{Citation for published version (APA):}

Baymul, C., \& Sen, K. (2020). Was Kuznets Right? New Evidence on the Relationship between Structural Transformation and Inequality. The Journal of Development Studies, 56(9), 1643-1662.

https://doi.org/10.1080/00220388.2019.1702161

\section{Published in:}

The Journal of Development Studies

\section{Citing this paper}

Please note that where the full-text provided on Manchester Research Explorer is the Author Accepted Manuscript or Proof version this may differ from the final Published version. If citing, it is advised that you check and use the publisher's definitive version.

\section{General rights}

Copyright and moral rights for the publications made accessible in the Research Explorer are retained by the authors and/or other copyright owners and it is a condition of accessing publications that users recognise and abide by the legal requirements associated with these rights.

\section{Takedown policy}

If you believe that this document breaches copyright please refer to the University of Manchester's Takedown Procedures [http://man.ac.uk/04Y6Bo] or contact uml.scholarlycommunications@manchester.ac.uk providing relevant details, so we can investigate your claim.

\section{OPEN ACCESS}




\section{Was Kuznets Right? New Evidence on the Relationship between Structural Transformation and Inequality}

\section{Cinar Baymul \& Kunal Sen}

To cite this article: Cinar Baymul \& Kunal Sen (2020): Was Kuznets Right? New Evidence on the Relationship between Structural Transformation and Inequality, The Journal of Development Studies, DOI: 10.1080/00220388.2019.1702161

To link to this article: https://doi.org/10.1080/00220388.2019.1702161

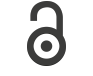

(c) 2020 UNU-WIDER. Published by Informa

UK Limited, trading as Taylor \& Francis Group

\section{$+$}

View supplementary material $๘$

册 Published online: 06 Jan 2020.

6 Submit your article to this journal

Џلll Article views: 525

Q View related articles $\sqsubset$

View Crossmark data 


\title{
Was Kuznets Right? New Evidence on the Relationship between Structural Transformation and Inequality
}

\author{
CINAR BAYMUL* \& KUNAL SEN (1D**** \\ *Global Development Institute, University of Manchester, Manchester, UK, **UNU-WIDER, Helsinki, Finland
}

\begin{abstract}
We examine the Kuznets postulate that structural transformation leads to higher inequality using comparable panel data for a large number of developing and developed countries for 1960-2012. Countries are in different stages of structural transformation, being either structurally underdeveloped, structurally developing or structurally developed. In contrast to the Kuznets hypothesis, we find that the movement of workers to manufacturing unambiguously decreases income inequality, irrespective of the stage of structural transformation that a particular country is in. We also find that the movement of workers into services has a positive impact on inequality across our set of countries at an early stage of structural transformation and a negative effect at a later stage, suggesting that the Kuznets postulate may apply more for services-driven structural transformation than manufacturing-driven structural transformation. Overall, our findings confirm the positive development effects that structural transformation relating to manufacturing may have in developing countries, not merely through higher growth but by reducing inequality as well. However, for many low-income countries, where the realistic possibility of structural transformation may be the movement of workers from agriculture to services, our findings suggest that inequality may increase with further structural transformation.
\end{abstract}

\section{Introduction}

Structural transformation - the movement of workers from low productivity to high productivity activities and sectors - is an essential feature of rapid and sustained growth. The speed at which structural transformation occurs differentiates successful countries from unsuccessful ones (Kuznets \& Murphy, 1966). At the same time, since Kuznets' seminal (1955) piece, it is widely believed that structural transformation can lead to higher inequality, at least initially. Therefore, rapid structural transformation may entail a trade-off between growth and inequality, which may be called the developer's dilemma (Sumner, 2017). As Kuznets argued, while inequality may increase at the early stages of structural transformation, beyond a certain level of structural transformation, inequality will decrease, giving rise to the famous inverted U-shaped relationship between income and inequality - the so-called Kuznets curve.

Several recent papers have looked at the relationship between structural transformation and economic growth (Comin, Lashkari, \& Mestieri, 2018; Diao, McMillan, \& Rodrik, 2017; Duarte \& Restuccia, 2010; Haraguchi, Cheng, \& Smeets, 2017; Herrendorf, Rogerson, \& Valentinyi, 2014; McMillan, Rodrik, \&

Correspondence Address: Kunal Sen, United Nations University World Institute for Development Economics Research, Katajanokanlaituri 6 B, FI-00160 Helsinki, Finland. E-mail: sen@wider.unu.edu

Supplementary Materials are available for this article which can be accessed via the online version of this journal available at https://doi.org/10.1080/00220388.2019.1702161 
Verduzco-Gallo, 2014). ${ }^{1}$ In this paper, we examine the inequality dimension of structural transformation. We re-examine the Kuznets postulate that at the early process of structural transformation, inequality increases as workers move from a sector with low average incomes and lower within-sector inequality - agriculture - to a sector with higher average income and higher within-sector inequality, such as manufacturing. We argue that both from conceptual and empirical standpoints, there are reasons to question the Kuznets view on the relationship between structural transformation and inequality. Firstly, from a conceptual point of view, a closer examination of the assumptions behind the Kuznets process makes clear that it is not obvious that a movement of workers from agriculture to manufacturing necessarily involves an increase in inequality. In contrast, the movement of workers from agriculture to services may have a different implication for inequality, as the assumptions that underlie the Kuznets argument on the positive effect of structural transformation on inequality is more likely to be true for the services-driven structural transformation.

Secondly, as we will document later in this paper, in contrast to what was envisaged by Kuznets, for many developing countries, the movement of workers from agriculture even in the early stage of structural transformation has been primarily to services and not to manufacturing. Given that few countries outside of East Asia have seen a typical path of structural transformation that was witnessed originally among the advanced market economies where workers first moved from agriculture to manufacturing and then on to services, it is not clear whether the implications of structural transformation for increasing inequality may be the same for the many different types of structural transformation that we observe in the developing and developed world.

Our historical data from 1960 to 2012 show three different stages of structural transformation. Firstly, there are a set of countries where the proportion of workers in agriculture is higher than any other sector for the most recent period for which we have the data - we call this set of countries structurally underdeveloped. These are mostly low-income countries. Secondly, for a set of countries, mostly in the middle-income category, the proportion of workers in services is higher than that in agriculture, though the share of workers in agriculture still higher than that in manufacturing. We call this set of countries structurally developing. Finally, we have a set of countries, which are a mix of middle- and high-income countries, where the share of workers in manufacturing is higher than that in agriculture. We call this set of countries structurally developed.

In this paper, we examine the inequality implications of structural transformation for a range of low, middle and high-income countries from 1960 to 2012, allowing for the heterogeneity of the stages of structural transformation that we observe in the data. We also allow for the possibility that manufacturing-driven structural transformation may have very different implications for inequality than services-driven inequality. To examine the structural transformation-inequality relationship, we use two high-quality data-sets, one for structural transformation and the other for income inequality. The data for structural transformation - that is, the share of workers in agriculture, manufacturing and services - comes from the Groningen Growth and Development Centre (GGDC) database, ${ }^{2}$ supplemented by additional data for low-income African countries provided by Mensah, Owusu, FosterMcGregor, and Szirmai (2018), which provides consistent annual data on sectoral employment for several low-, middle-, and high-income countries from the 1950s onwards and the data for inequality comes from the most recent revisions to the World Income Inequality Database (WIID) which provides comparable inequality data over time for a large number of countries. ${ }^{3}$

Using the GGDC and WIID databases and panel data methods, we find that the Kuznets postulate does not hold true for manufacturing-driven structural transformation. No matter at what stage of structural transformation a county may be in, manufacturing unambiguously decreases inequality the marginal effect of an increase in manufacturing employment share on income inequality (as measured by the Gini) is always negative and statistically significant, at all levels of manufacturing employment share. In contrast, we find that the marginal effect of an increase in the share of workers in services is positive on inequality for structurally developing countries, and negative for structurally developed countries, a process which is more in line with the original Kuznets argument. Given that the bulk of the movement of workers from agriculture are going to services and not to manufacturing 
in many low-income countries, this suggests that the Kuznets argument holds with greater force in contemporary times, but not in the manner envisaged by Kuznets and other scholars.

The rest of the paper is in six sections. In the next section, we discuss the argument proposed by Kuznets on the relationship between structural transformation and inequality, known in the literature as the Kuznets process. In Section 3, we describe the patterns of structural transformation in our sample of countries. In Section 4, we provide descriptive evidence on the relationship between structural transformation and inequality. In Section 5, we discuss the econometric methodology. We present our results in Section 6. Section 7 concludes.

\section{The Kuznets process}

In his classic 1955 paper, Kuznets suggested that in the early phase of economic development, inequality will increase. At a later phase of economic development, as governments follow redistributive policies combining progressive taxation with welfare spending, inequality may decrease. The core of Kuznet's argument on the relationship between inequality and development is captured in the following paragraph extracted from his 1955 paper:

An invariable accompaniment of growth in developed countries is the shift away from agriculture, a process usually referred to as industrialization and urbanization. The income distribution of total population in the simplest model, may therefore be viewed as a combination of the total income distributions of the rural and urban populations. What little we know of the structure of the two component income distributions reveals that a) the average per capita income of the rural population is usually lower than that of the urban; b) inequality in the percentage shares within the distribution for the rural population is somewhat narrower than that in the urban population.... Operating with this simple model, what conclusions do we reach? First, all other conditions being equal, the increasing weight of the urban population means an increasing share for the more unequal of the two component distributions. Second, the relative difference in per capita income between the rural and urban populations does not necessarily shift downward in the process of economic growth; indeed, there is some evidence to suggest that it is stable at best, and tends to widen because per capita productivity in urban pursuits increases more rapidly than in agriculture. If this is so, inequality in total income distribution should increase. (pp. 7-8)

The Kuznets process of widening inequality with structural transformation (that is, movement of workers away from agriculture) can be described as composed of two sub-processes: i) between-sector inequality: a movement of the population from a sector characterised by lower mean income to a sector characterised by higher mean income, and ii) within-sector inequality: the movement of the population from a sector with low within-sector inequality to a sector with higher within-sector inequality. If both sub-processes work in the same direction - that is, if the movement of workers is from a sector with both a low mean and low variance in incomes to a sector with a higher mean and high variance in incomes, then structural transformation will unambiguously increase inequality. However, if the movement of workers is from a sector with low mean income but higher variance of income to a sector with a higher mean income but lower variance in income, then it is less obvious that inequality will necessarily increase.

Following Anand and Kanbur (1993a), we provide a diagrammatic exposition of the Kuznets process to make clear the contribution of between-sector (or group) inequality and within-sector (or group) inequality to overall inequality. ${ }^{4}$ Let I be the overall measure of inequality in a given country and let $\mathrm{x}$ be the share of workers in the non-agricultural sector. For the sake of exposition, let us assume that there is only one non-agricultural sector, so that we do not make a distinction between the manufacturing and services sectors. Let the working population of the country be normalised to one. Define between-sector (or group) inequality as the inequality in the income distribution when a fraction $\mathrm{x}$ of the working population receives income $\mathrm{u}_{1}$ and the remaining fraction, $1-\mathrm{x}$, receives income $\mathrm{u}_{2}$ (where between-group inequality is defined as the value of the inequality measure when everyone in the sector receives the mean 
income of the sector). Following Kuznets, we can assume that the mean income of the non-agricultural sector is higher than that of the agricultural sector - that is, $\mathrm{u}_{1}>\mathrm{u}_{2}$.

It is clear from between-group inequality must be zero at both $\mathrm{x}=0$ and $\mathrm{x}=1$, and must be positive elsewhere - that is, when all workers are either in the agricultural sector or in the non-agricultural sector, there can be no between-group inequality. However, in the range where $\mathrm{x}$ is higher than 0 but less than 1 , inequality will first increase with increasing $\mathrm{x}$, then fall (as captured in Figure 1). This is because with low $\mathrm{x}$, there are more workers in the low-income sector (in our example, agriculture) than in the high-income sector, so that between-sector income differences are considerable. However, once a larger proportion of workers are in the high-income sector, between-group inequality starts falling, till it reaches zero when all workers are in the high-income sector.

Now consider the behaviour of within-group inequality. Defining within-group inequality as the difference between overall inequality and between-group inequality, its movement with the increase in $\mathrm{x}$ will depend on the assumptions that one makes on within-group inequality in the non-agricultural sector versus the agricultural sector. If one assumes that there is higher within-group inequality in the non-agricultural sector than in the agricultural sector (as seem to be implied by Kuznets), then the within-group inequality component of overall inequality will strictly increase as $\mathrm{x}$ increases - that is, within-group inequality will increase with structural transformation (as shown in Figure 1).

The combination of the behaviour of between-group inequality and within-group inequality may lead to the well-known inverted relationship between structural transformation and inequality - in Figure 1, as $\mathrm{x}$ increases, there is an unambiguous increase in inequality; however, once a certain $\mathrm{x}$ is reached, if the between-group component dominates the within-group component, inequality will start declining.

The Kuznets process as described above does not differentiate between whether the movement of workers from agriculture is to manufacturing or services. Would the effects of manufacturing-driven structural transformation be different than that for services-driven structural transformation? Consider between-group-inequality first. For this component to increase with structural transformation, mean income in the sector absorbing labour from agriculture has to be higher than the mean income prevailing in the agricultural sector. This assumption is likely to hold, no matter whether the labour absorbing sector is manufacturing or services as productivity in the manufacturing or services sector

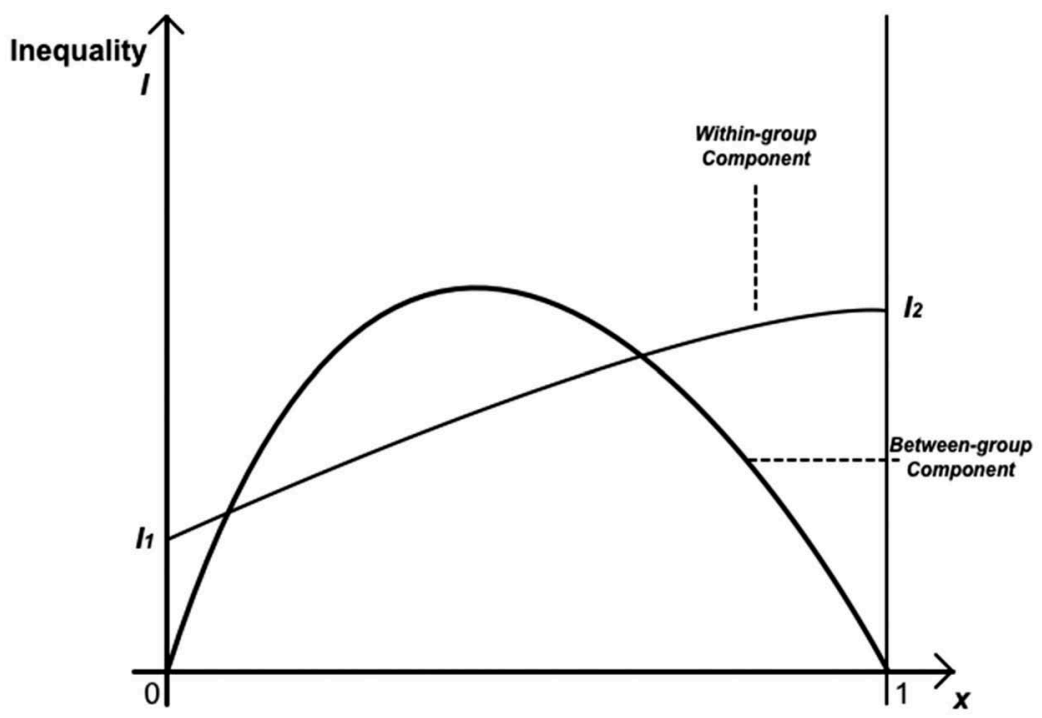

Figure 1. The Kuznets process.

Source: Adapted from Anand and Kanbur (1993a). 
is expected to be higher than in agriculture, at least in the early part of industrialisation when agriculture is likely to be characterised by surplus labour (Lewis, 1954). ${ }^{5}$

Now consider within-sector inequality. This component of overall inequality may not necessarily increase with manufacturing-driven structural transformation for three reasons. Firstly, the historical experience of successful industrialisation among what are called the 'late industrialisers' - for example, China, Mauritius, South Korea, Singapore, and Taiwan - indicates that much of the early success in industrialisation occurs in labour-intensive manufacturing, which is characterised by low within-sector inequality (Krueger, 1980; World Bank, 2017). Secondly, manufacturing activity tends to be factory based and in the formal sector (in contrast to the services sector, where a large part of economic activity is in the informal sector), where labour markets are characterised by minimum wages and other labour regulations. This is likely to lead to wage compression, and therefore, relatively low within-sector inequality. Finally, there may be a political channel through which within-sector inequality may decrease with manufacturing-driven structural transformation as the organised working class is likely to gain political strength over time in countries which witness rapid industrialisation. This may lead to democratisation that may encourage redistribution (Acemoglu \& Robinson, 2002).

However, a very different argument may apply to services-driven structural transformation. A large of part of the employment created in the services may be self-employment in the poorly paid informal sector (such as household enterprises in the trade, hotels and restaurants sector), which may exist with well-paid jobs in the formal services sector (such as banking and finance). The lack of an organised working class in the informal services sector also does not allow workers to make demands of their employers for better wages or of the state for redistribution. This suggests that the Kuznets argument, which proposes that the move of workers from agriculture to non-agriculture will exacerbate the within-sector component of inequality, is likely to hold more for the services sector than the manufacturing sector.

We illustrate the possibility of the within-sector component of inequality falling with a movement of workers from agriculture to manufacturing in Figure 2. Here, the within-group inequality component falls with an increase in $\mathrm{x}$. As is clear from the figure, it is not obvious that inequality will necessarily increase at early stages of structural transformation - if the within-group component of

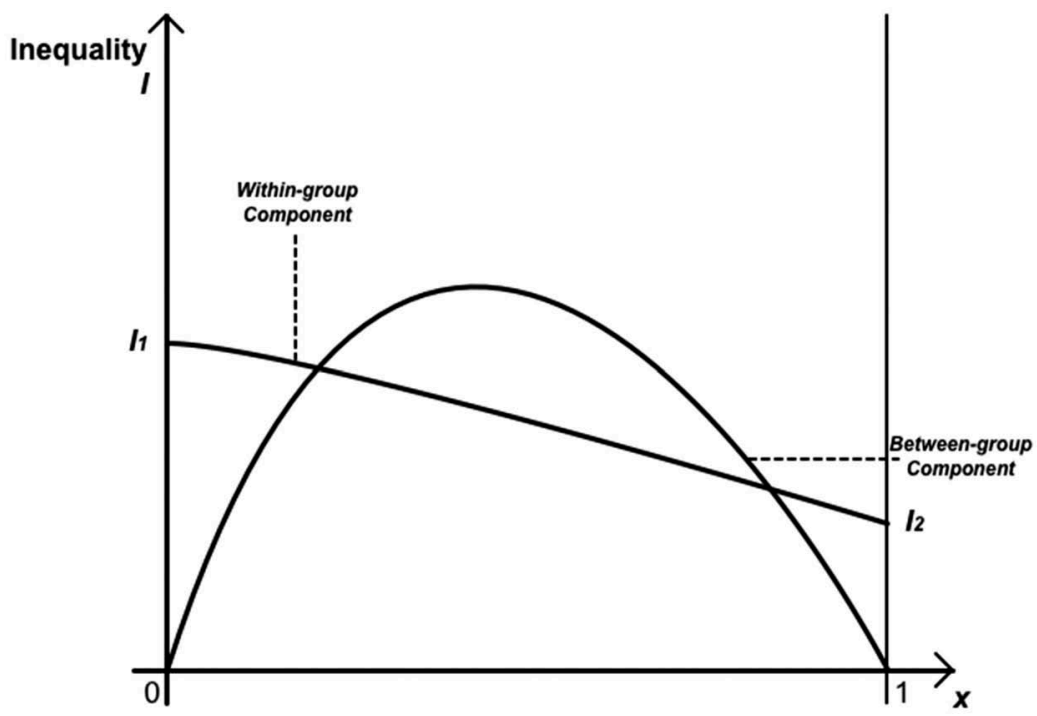

Figure 2. An alternate view of the Kuznets process. Source: Adapted from Anand and Kanbur (1993a). 
inequality dominates the between-group component, inequality will fall with an increase in the number of workers in the non-agricultural sector. ${ }^{6}$

\section{Stages of structural transformation}

In this section, we categorise countries according to the stage of structural transformation that they are in. We describe the data we use in our analysis in the Appendix.

We categorise our countries by the different stages of structural transformation that they are in. The first set of countries are those where agriculture is still the largest sector in terms of the share of employment in the most recent time period available. In our sample, these countries are Burkina Faso, Cameroon, Ethiopia, India, Kenya, Malawi, Mozambique, Nigeria, Rwanda, Senegal, Tanzania, Uganda, and Zambia. These countries are all in Sub-Saharan Africa, with only India being the non-African country. We call these countries structurally underdeveloped. The next set of countries are where more people are employed in the services sector than agriculture, with agriculture being the second largest sector. These countries are Bolivia, Botswana, Brazil, China, Colombia, Costa Rica, Egypt, Ghana, Indonesia, Lesotho, Morocco, Namibia, Philippines, Peru, Philippines, Thailand and South Africa. We call them structurally developing countries. These countries span all three continents - Africa, Asia, and Latin America. The final set of countries has more people employed in manufacturing sector than agriculture. These countries in the sample are Argentina, Chile, Hong Kong, Malaysia, Mauritius, Mexico, Singapore, South Korea, Taiwan, and Venezuela, as well as Denmark, France, Italy, Japan, Netherlands, Spain, Sweden, the United Kingdom and the United States. These countries are either in East Asia or Latin America (with the exception of Mauritius, which is in Africa), and the advanced market economies. We call these countries structurally developed. We provide the list of countries by stage of structural transformation in Table A1.

In Figure 3, we provide the allocation of workers by stage of structural transformation, averaged over the entire period, 1960-2012. The broad sectors we look at are agriculture, manufacturing industry, nonmanufacturing industry (mining, utilities, and construction) and services. Agriculture provides under 77 per cent of the employment for structurally underdeveloped countries, just over 43 per cent in structurally developing countries and around 13 per cent in structurally developed countries. For the period 1960-2012, Manufacturing provided an average of 4 per cent of employment in structurally underdeveloped countries, 11 per cent of employment in structurally developing countries and 20 per cent of employment in structurally developed countries. Finally, services provided an average of 17 per cent of employment in structurally underdeveloped countries, with only under 0.6 per cent being business services. Business services employed 3 per cent on average in structurally developing countries while the total services share was 38 per cent. Services is provided 58 per cent of employment in structurally developed countries and business services' share was 8 per cent.

In Table 1, we provide the same information as in Figure 3, except now we do it by sub-periods. We see the very slow movement of workers in agriculture in structurally underdeveloped countries, from 81 per cent in 1960-1979 to 69 per cent in 2000-2012. These countries have also seen a slow increase in the share of employment in manufacturing from 4 per cent in 1960-1979 to around 6 per cent in 2000-2012. In the case of structurally developing countries, average share of employment in services overtakes employment in agriculture only in the period between 2000 and 2012. Nevertheless, these countries have seen rapid decline in the share of employment in agriculture from 55 per cent in 1960-79 to 31 per cent in 2000-2012, as well as an increase in the share of employment in manufacturing from 10 per cent in 1970-1979 to around 12 per cent in 2000-2012. For structurally developed, the share of employment in agriculture was low to start with at 20 per cent in 1970-1979. By the time we reach the period 2000-2012, more workers are employed in nonmanufacturing industry in these countries than in agriculture, and services at 69 per cent provide the largest employment by far. Here, we observe a fall in the share of employment in manufacturing over time. 


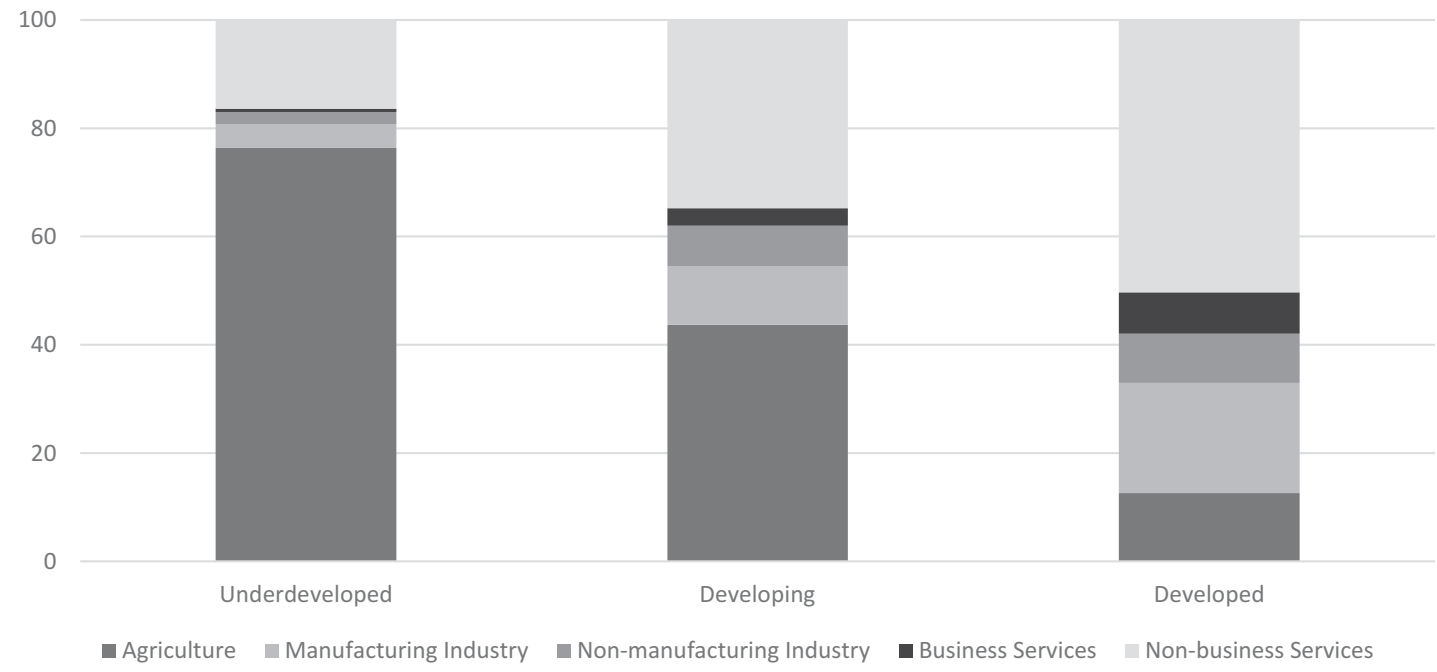

Figure 3. Share of employment by stages of structural transformation. Note: In percentages of total employment, unweighted averages. Source: GGDC data and Mensah et al. (2018), our calculations.

Table 1. Share of employment by stages of structural transformation over time

\begin{tabular}{lcccccc}
\hline Country group & Period & Agriculture & $\begin{array}{c}\text { Manufacturing } \\
\text { industry }\end{array}$ & $\begin{array}{c}\text { Non-manufacturing } \\
\text { industry }\end{array}$ & $\begin{array}{c}\text { Business } \\
\text { services }\end{array}$ & $\begin{array}{c}\text { Non-business } \\
\text { services }\end{array}$ \\
\hline Underdeveloped & $1960-1979$ & 81.3 & 3.8 & 2.0 & 0.4 & 12.5 \\
& $1980-1999$ & 77.7 & 3.8 & 2.0 & 0.5 & 15.9 \\
Developing & $2000-2012$ & 68.8 & 5.5 & 3.0 & 0.8 & 21.8 \\
& $1960-1979$ & 55.1 & 10.0 & 6.5 & 2 & 26.5 \\
& $1980-1999$ & 41.3 & 11.3 & 7.8 & 3 & 36.6 \\
Developed & $2000-2012$ & 31.2 & 11.5 & 8.1 & 5.3 & 43.9 \\
& $1960-1979$ & 20.1 & 22.9 & 9.4 & 4.2 & 43.4 \\
& $1980-1999$ & 10.5 & 20.9 & 8.9 & 7.7 & 52 \\
& $2000-2012$ & 6.2 & 15.8 & 9.1 & 12 & 57 \\
\hline
\end{tabular}

Note: In percentages of total employment, unweighted averages.

Source: GGDC data and Mensah et al. (2018), our calculations.

A striking feature of structural transformation in our 48 countries is that the movement of employment from agriculture has been mostly to services (Figure 4(a)). For structurally underdeveloped countries, there has been an increase in the movement of workers away from agriculture since the 1990s till the recent period, which is when several of these countries witnessed fairly strong growth (Arndt, McKay, \& Tarp, 2016) (Figure 4(b)). We observe a rapid and sustained movement of workers from agriculture to manufacturing and services in structurally developing countries over the entire period 1960-2012 (Figure 4(c)). Finally, for structurally developed countries, the movement of workers from agriculture is mostly to services, with the movement of workers from agriculture to manufacturing falling over time (Figure 4(d)).

A second striking feature of structural transformation has been that the shift of employment from agriculture to services has been accompanied by falling relative productivity of services to agriculture (Figure 5(a)). ${ }^{7}$ In contrast, the relative productivity of manufacturing to agriculture has increased till 
a

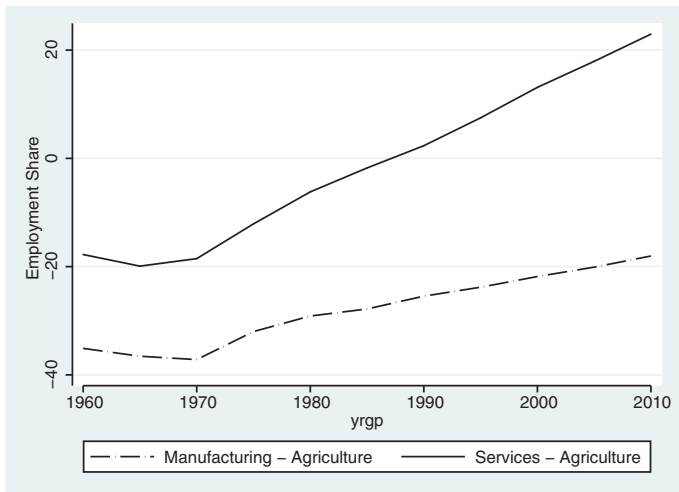

C

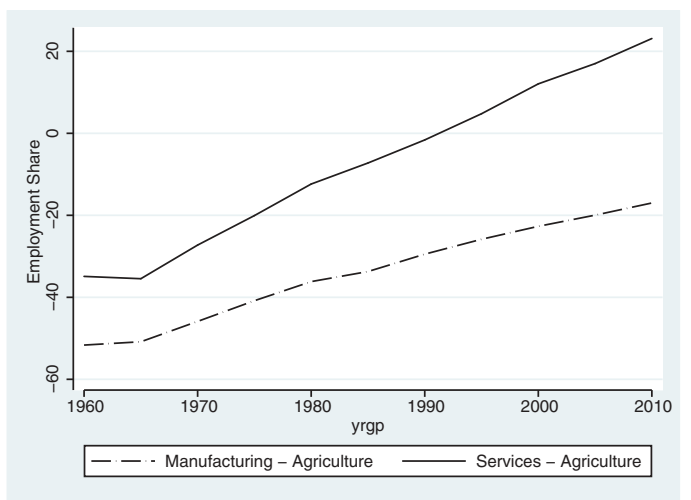

b

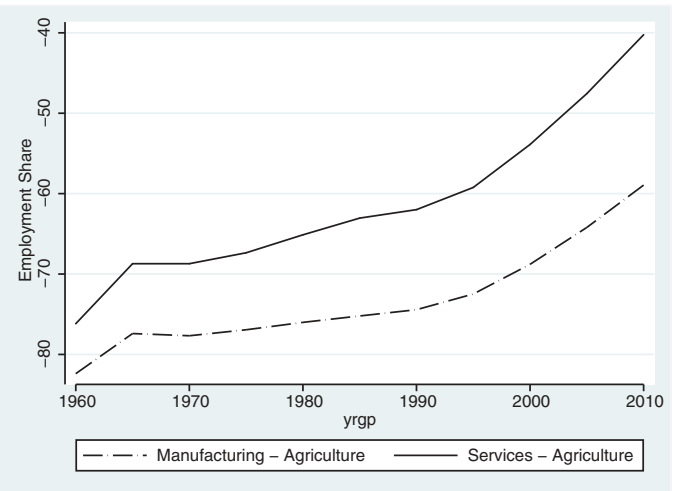

d

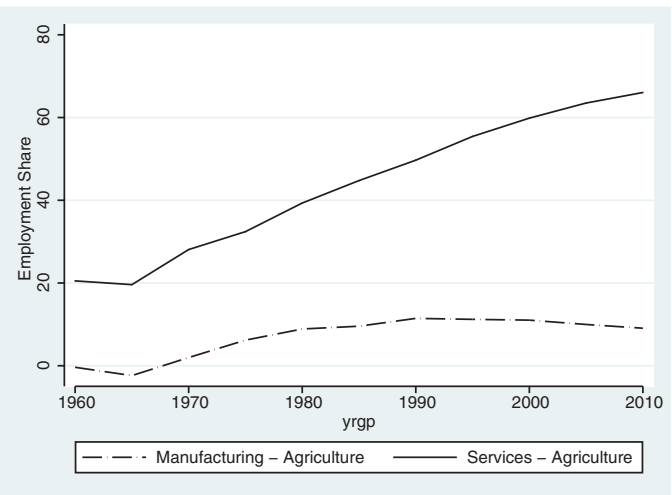

Figure 4. Movement of workers from agriculture to manufacturing and services over time. (a) all countries. (b) structurally underdeveloped countries. (c) structurally developing countries. (d) structurally developed countries. Note: Manufacturing-Agriculture: Employment Share in Manufacturing - Employment Share in Agriculture, Manufacturing-Services: Employment Share in Services - Employment Share in Agriculture; unweighted averages.

Source: GGDC data and Mensah et al. (2018), our calculations.

the 1970s, then showed a decline until the 1980s, and is significantly higher than the relative productivity of the services sector since mid-1980s. This suggests that a services-driven structural transformation has very different implications for overall productivity growth as compared to a manufacturing-driven structural transformation (Herrendorf et al., 2014). ${ }^{8}$ We also observe very different patterns of relative productivity movements over time across the three different country groups - consistent with the slow movement of workers from agriculture to manufacturing, manufacturing relative productivity levels are very similar to that of services in structurally underdeveloped countries (Figure 5(b)). In contrast, for structurally developing countries, the relative productivity of manufacturing is significantly higher than that of services (Figure 5(c)). For structurally developed countries, where agricultural productivity levels are high relative to what we observe in structurally underdeveloped and developing countries (see Gollin, Lagakos, \& Waugh, 2014), relative productivity differences across sectors become insignificant over time as more workers move out of agriculture (Figure 5(d)).

In the previous section, we argued that one key assumption behind the Kuznets process - that the within-sector component of total inequality will increase at the early stages of structural transformation may not necessarily hold if the movement of workers from agriculture is to manufacturing. We now 
a

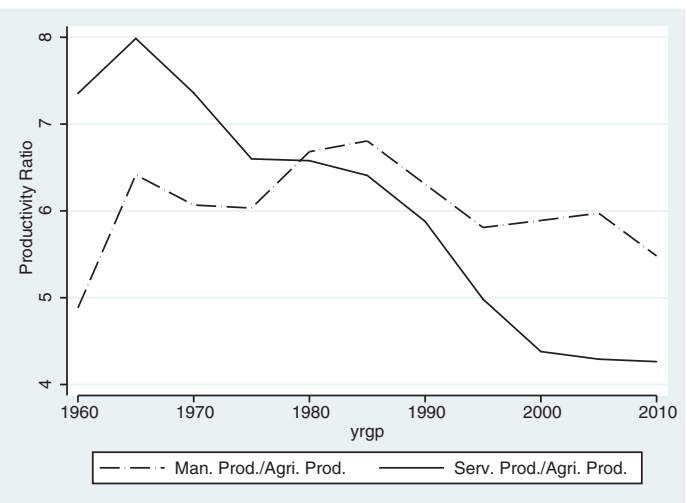

C

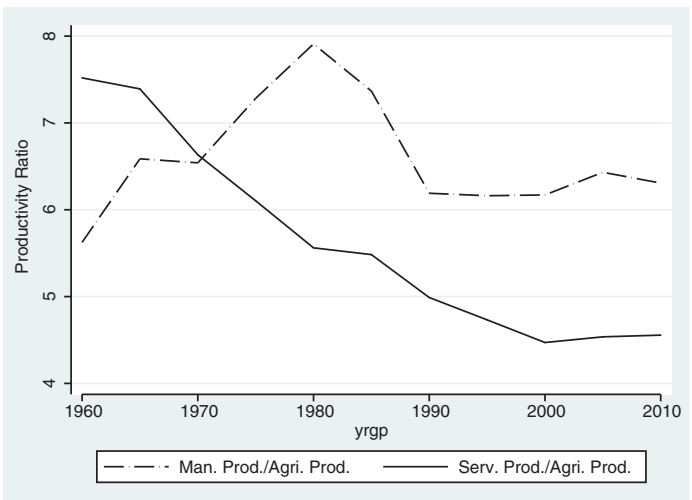

b

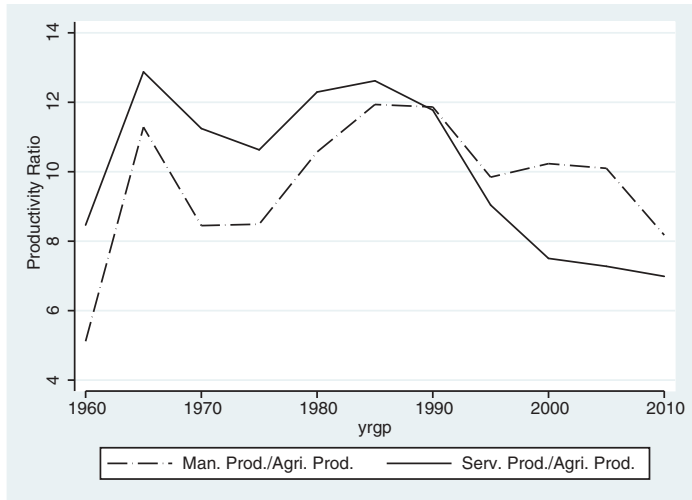

d

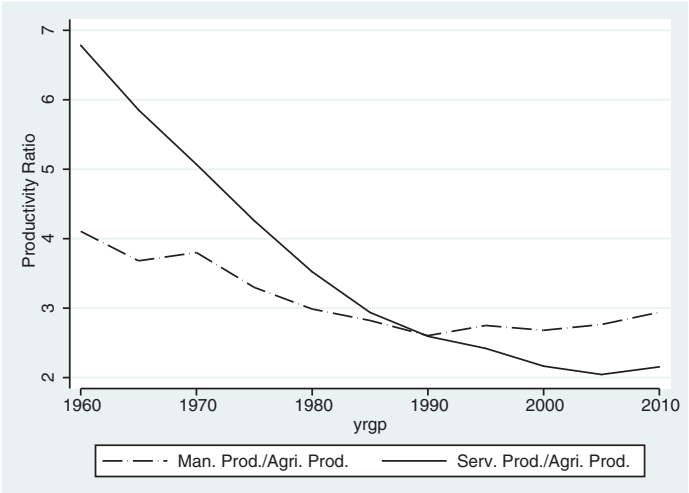

Figure 5. Relative productivity differentials over time. (a) All countries. (b) Structurally underdeveloped countries. (c) Structurally developing countries. (d) Structurally developed countries.

Note: Manufacturing Prod./Agri Prod.: Real Value Added per Worker in Manufacturing as Ratio of Real Value Added per Worker in Agriculture; Services Prod./Agri Prod.: Real Value Added per Worker in Services as Ratio of Real Value Added per Worker in Agriculture; unweighted averages.

Source: GGDC data and Mensah et al. (2018), our calculations.

provide some suggestive evidence to support our claim that manufacturing in the early stages of structural transformation may not be characterised by high within-sector inequality. To capture within-sector inequality manufacturing, we use the Theil measure of within industry pay inequality as calculated by the University of Texas Inequality Project (UTIP) using industry-specific wage data from the United Nations Industrial Development Organisation (UNIDO)'s industrial statistics database (see Galbraith, Halbach, Malinowska, Shams, \& Zhang, 2014). We present the relationship between manufacturing employment share and the Theil measure of within industry pay inequality by our country groups in Figure 6. We observe that for structurally developing and developed countries, within-sector inequality in manufacturing decreases with increases in the manufacturing employment share (this is not the case for the structurally underdeveloped countries, where we see an U-shaped relationship). Particularly for countries where the share of employment in manufacturing has been very high (at over 20 per cent) in certain periods such as Hong Kong, Malaysia, Mauritius and Taiwan, the decreases in within-sector inequality can be explained by the fact that much of the increase in employment occurred in the labourintensive manufacturing sectors (Krueger, 1978; Riedel, 1988)

What about within-sector inequality in services? We do not have data on mean incomes by sub-sector in services to allow us to compute within-sector inequality in services. However, using productivity as 


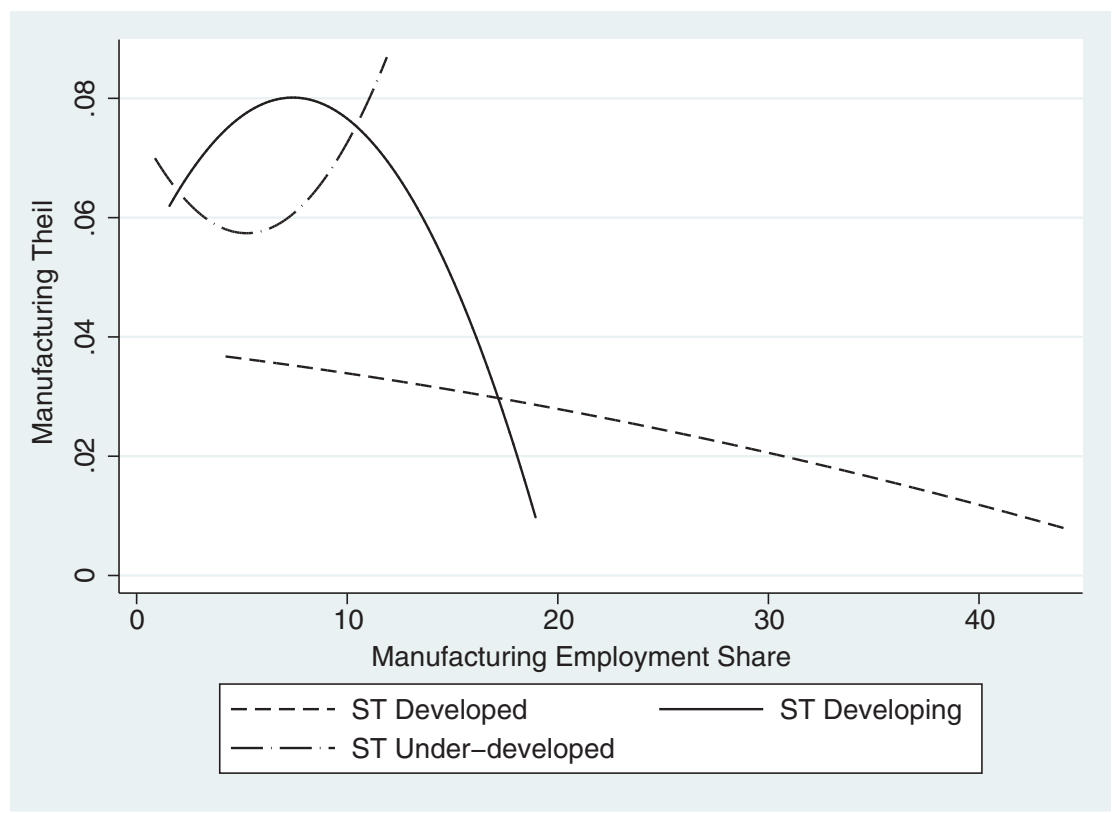

Figure 6. Structural transformation and within-sector inequality in manufacturing. Source: https://utip.lbj.utexas.edu/data.html, our calculations.

a proxy for mean incomes at the sub-sectoral level, we find clear differences in relative productivity levels across sub-sectors - the Business Services sub-sector which comprise finance, banking and information technology, is far more productive than all other Services sub-sectors (Figure 7).

Overall, our analysis of the patterns of structural transformation suggests that different countries in Africa, Asia, Europe and North America and Latin America are in very different stages of structural transformation, both in the across-sector movement of workers as well as the behaviour of relative productivities over time at the sectoral level. We next discuss the implications of these different stages of structural transformation for inequality.

\section{Patterns of structural transformation and inequality}

Data for income inequality are taken from the standardised income inequality dataset (WIID) of the World Institute for Development Economics Research (WIDER). This data-set has been used extensively in the literature (see Ackland et al. 2013; Roope, Nino-Zarazua, \& Tarp, 2018), and is widely regarded as the most reliable data on inequality for developing (and developed) countries. We use Net Ginis, which measure net per capita income inequality in a country in a given year.

We first look at the overall relationship between manufacturing employment share and inequality, then by country group. In the overall sample as well as by country group, we see a clear negative relationship between manufacturing-driven structural transformation and inequality (Figure 8(a) and 8(b)).

We next look at the relationship between services employment share and inequality, for the overall sample and then by country group (Figure 9(a) and 9(b)). We do not see a clear relationship in the overall sample, with a lack of precision in the fitted line estimated in the scatter plot. By country group, we seem to see a U-shaped relationship for structurally underdeveloped countries, a positive relationship for structurally developing and a negative relationship for structurally developed countries. Overall, the scatter plots suggest that there is a negative relationship between manufacturing-driven structural transformation and inequality and a lack of a clear relationship between services-driven structural transformation and inequality. We now proceed to an econometric analysis of the relationship between structural transformation and inequality. We next discuss the econometric methodology that we will use in the analysis. 


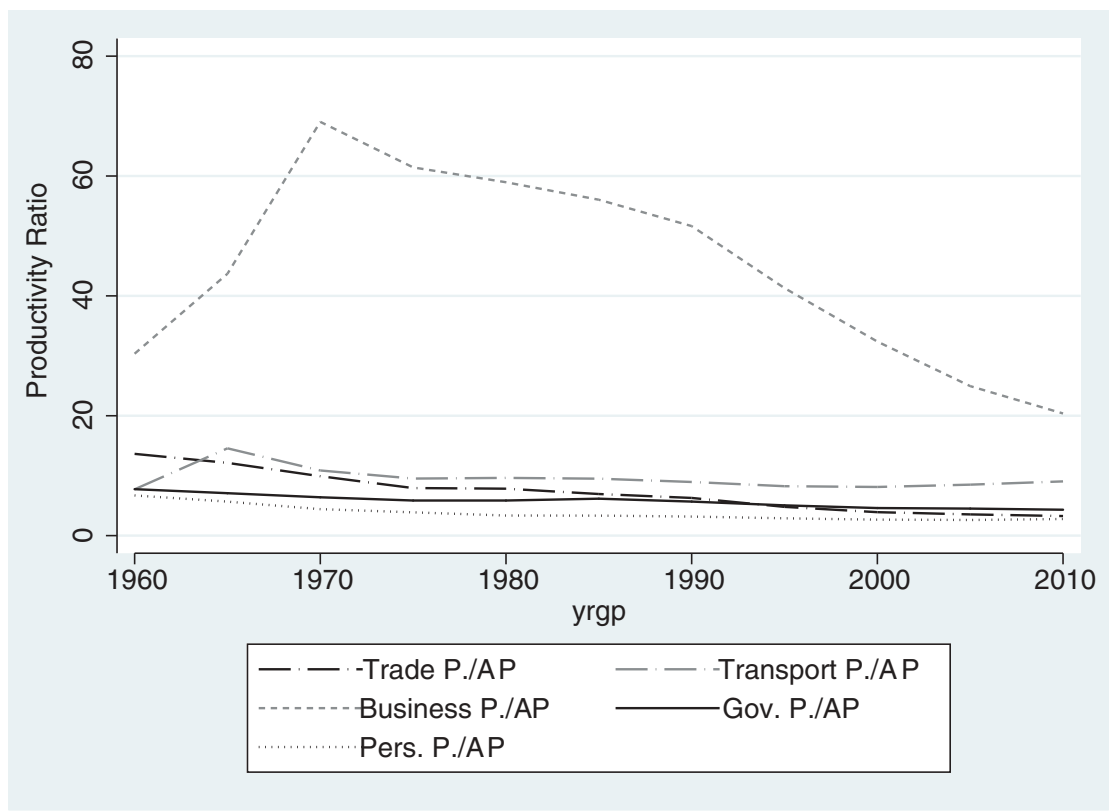

Figure 7. Relative productivity within services sector over time, all countries.

Notes: Trade P./AP: Real Value Added per Worker in Trade Services as Ratio of Real Value Added per Worker in Agriculture; Transport P./AP: Real Value Added per Worker in Transport Services as Ratio of Real Value Added per Worker in Agriculture; Business P./AP: Real Value Added per Worker in Business Services as Ratio of Real Value Added per Worker in Agriculture; Govt P./AP: Real Value Added per Worker in Government Services as Ratio of Real Value Added per Worker in Agriculture; Pers. P./AP: Real Value Added per Worker in Personal, Social and Community Services as Ratio of Real Value Added per Worker in Agriculture; unweighted averages. Source: GGDC data and Mensah et al. (2018), our calculations.

\section{Methodology}

Our paper has two core research questions: (a) what are the effects of manufacturing-driven structural transformation on income inequality, and do the effects differ by the path of structural transformation a country is in and (b) what are the effects of services-driven structural transformation on income inequality, and how are they different from the effects of manufacturing- driven structural transformation? To address these two research questions, we estimate the marginal impact of an increase in the shares of employment in manufacturing and services on inequality with the two following equations:

$$
\begin{aligned}
\text { Gini }_{i t}= & \beta_{1} \text { Manufacturing }_{i t}+\beta_{2} \text { Manufacturing }_{i t}^{2}+\beta_{3} \text { Nonmanufacturing }_{i t} \\
& +\beta_{4} \text { Services }_{i t}+\beta_{5} \text { Services }_{i t}^{2}+\beta_{X} X_{i t}+\sigma_{t}+a_{i}+u_{i t}
\end{aligned}
$$

$$
\begin{aligned}
& \text { Gini }_{i t}=\beta_{1} \text { Manufacturing }_{i t}+\beta_{2} \text { Manufacturing }_{i t}{ }^{2}+\beta_{3} \text { Developed } * \text { Manufacturing }_{i t} \\
& +\beta_{4} \text { Developing } * \text { Manufacturing }{ }_{i t}+\beta_{5} \text { Developed } * \text { Manufacturing }_{i t}{ }^{2} \\
& +\beta_{6} \text { Developing } * \text { Manufacturing }{ }_{i t}^{2}+\beta_{7} \text { Nonmanufacturing }_{i t} \\
& +\beta_{8} \text { Services }_{i t}+\beta_{9} \text { Services }_{i t}^{2}+\beta_{10} \text { Developed } \text { Services }_{i t}+\beta_{11} \text { Developing } * \text { Services }_{i t}
\end{aligned}
$$

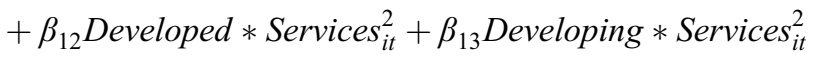

$$
\begin{aligned}
& +\beta_{14} \text { Developed }_{i}+\beta_{15} \text { Developing }_{i}+\beta_{X} X_{i t}+\sigma_{t}+a_{i}+u_{i t}
\end{aligned}
$$


a

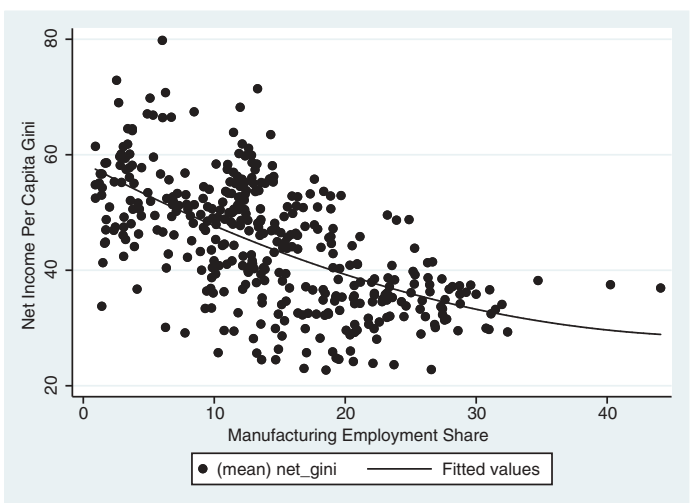

b

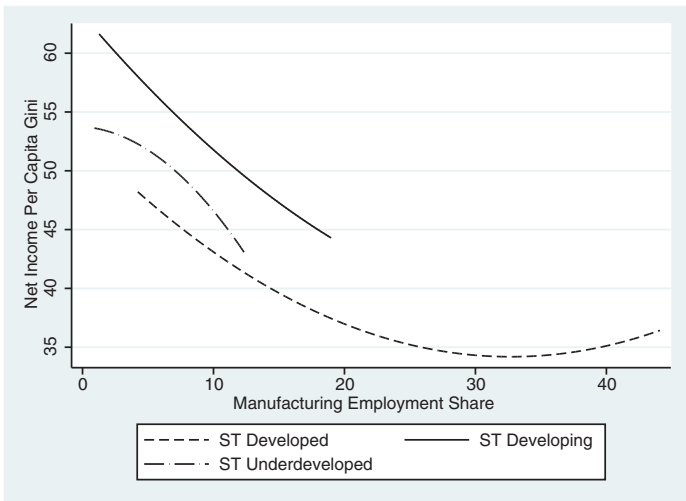

Figure 8. The relationship between manufacturing employment share and inequality. (a) All countries. (b) Different paths of structural transformation.

Source: GGDC, Mensah et al. (2018) and WIID data, our calculations.

a

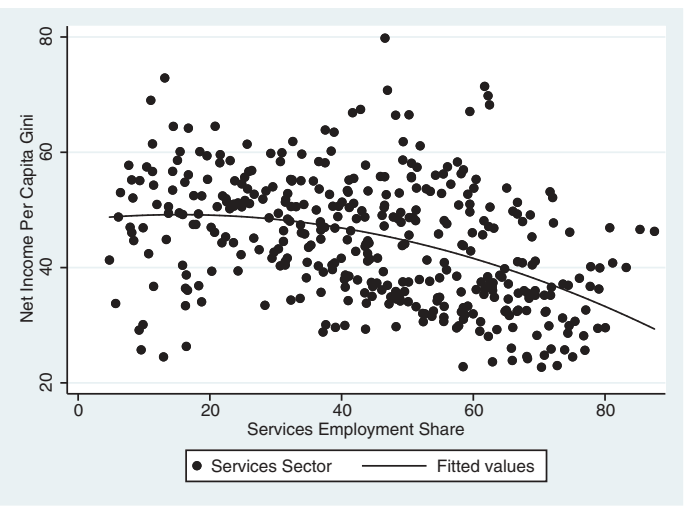

b

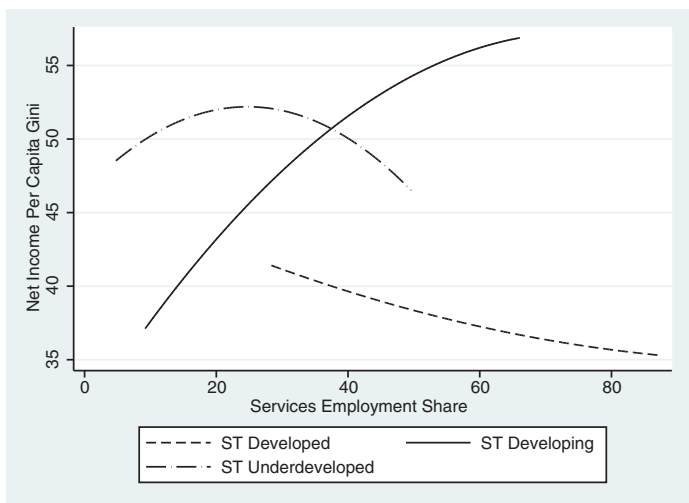

Figure 9. The relationship between services employment share and inequality. (a) All countries. (b) Different paths of structural transformation.

Source: GGDC, Mensah et al. (2018) and WIID data, our calculations.

where $i$ denotes the country, and $t$ denotes the period. Manufacturing, Nonmanufacturing and Services are the employment shares of country $i$ in period $t$ in these sectors. ${ }^{9}$ Since we are interested in the marginal impact of manufacturing employment share on inequality, we control for the employment shares of the other sectors. $X$ is a vector of other controls, which we discuss below, and $\sigma t$ and $a i$ are period and country dummies, respectively. ${ }^{10}$

We measure income inequality using the Net Per Capita Gini - that is, the level of income inequality in the country net of Taxes and Transfers. The net Gini allows us to capture the indirect effect that structural transformation may have on inequality through what we called the political channel - the demand for redistribution that may originate from the organised working class if there is an increase in the share of employment in manufacturing. However, it is not obvious if it should be the preferred measure of inequality over the Gross Gini - which captures the direct effect of structural transformation on market inequality. We also use the Gross Gini as an alternate dependent variable in our econometric analysis. 
In Equation (1), we allow a non-linear effect of manufacturing and services employment shares on inequality - as suggested by the Kuznets postulate that inequality may first increase, then decrease with structural transformation (such a quadratic relationship between employment share and inequality would not be expected for nonmanufacturing). In Equation (2), we allow for the effect of manufacturing employment share on inequality to differ by the stage of structural transformation a particular country is in, so we interact the manufacturing employment share with the dummies for whether the country is structurally developing or developed (the residual is if the country is structurally underdeveloped).

With respect to the control variables, we begin with a parsimonious sector of controls - these are per capita income, human capital, trade and government consumption (to capture the size of the government sector). Per capita income may have an independent effect on inequality (by providing more resources for redistribution) over and above through the effect of structural transformation on the level of economic development. Countries with higher levels of human capital are likely to see lower inequality as a higher supply of human capital would lead to lower wage inequality (CastelloCliment \& Doménech, 2014). At the same time, a larger supply of more educated workers may lead to the growth of more sophisticated service sector activities (such as business services), which may increase inequality. Trade may lower inequality by increasing the demand and wages for abundant low-skilled workers (Goldberg \& Pavcnik, 2007). On the other hand, trade can increase inequality though trade induced technological progress that is biased towards skilled labour and capital (Feenstra \& Hanson, 2003; Wood, 1994). Finally, the larger the size of the government, the lower may be inequality (Dabla-Norris, Kochhar, Suphaphiphat, Ricka, \& Tsounta, 2015). ${ }^{11}$ In further robustness tests, which we discuss in Section S6 in the Supplementary Materials, we also include financial globalisation and foreign direct investment as additional controls.

We estimate Equation (1) by panel fixed effects regressions to control for time-invariant country characteristics (such as the country's factor endowments) that may explain both the pattern of structural transformation and inequality. ${ }^{12}$ We estimate Equation (2) by random effects first, as it contains time-invariant dummy variables for structurally developing and developed countries that need to be estimated. Additionally, we also estimate Equation (2) using fixed effects regressions. Fixed effects regressions do not allow us to identify the impact of time-invariant dummy variables on the dependent variable; however, we are able to examine how the impact of the shares of employment in manufacturing and services on income inequality differ amongst the country groups. We also include period dummies to control for common global shocks that may affect structural transformation and inequality. ${ }^{13}$ We use five-year averaged data to take into account the infrequent nature of the data on income inequality. We have 389 observations for the 48 countries for the period 1960-2012 in the base model without controls and 364 observations in the augmented model with controls.

\section{Results}

We present the results of the set of panel regressions that aim to investigate the relationship between the manufacturing and services employment shares and income inequality in Table 2 and the marginal effects of manufacturing and services employment shares on inequality in Table $3 .{ }^{14}$ Cols. (I) and (II) present the estimates of Equation (1) with and without our basic controls. Cols. (III) and (IV) present the random effects estimates of Equation (2), with and without basic controls, with country groups interacted with manufacturing employment share. Cols (V) and (VI) rerun the same equation, and in the same sequence, using fixed effects.

We begin with a discussion of the effect of an increase in the share of employment in manufacturing on inequality. The fixed effect estimates in the Cols. (I) and (II) suggest that an increase in manufacturing employment share decreases income inequality - the coefficient on the manufacturing employment share is negative and significant at 10 per cent level of significance or below. The significance of the squared manufacturing variable in Cols. I and II suggests that there is a quadratic Kuznets-type relationship exists between manufacturing and inequality. With respect to other control 
Table 2. Regression results

\begin{tabular}{|c|c|c|c|c|c|c|}
\hline & I & II & III & IV & V & VI \\
\hline & FE I & FE II & RE I & RE II & FE III & FE IV \\
\hline Manufacturing & $\begin{array}{l}-0.745^{* *} \\
(0.323)\end{array}$ & $\begin{array}{l}-1.051^{* *} \\
(0.456)\end{array}$ & $\begin{array}{c}-3.451^{*} \\
(1.784)\end{array}$ & $\begin{array}{l}-4.064^{* *} \\
(1.965)\end{array}$ & $\begin{array}{c}-3.853^{*} \\
(2.176)\end{array}$ & $\begin{array}{l}-4.545 \\
(2.963)\end{array}$ \\
\hline Manufacturing $^{2}$ & $\begin{array}{c}0.008 \\
(0.006)\end{array}$ & $\begin{array}{c}0.012 \\
(0.008)\end{array}$ & $\begin{array}{c}0.189 \\
(0.122)\end{array}$ & $\begin{array}{c}0.215^{*} \\
(0.125)\end{array}$ & $\begin{array}{c}0.233 \\
(0.158)\end{array}$ & $\begin{array}{c}0.250 \\
(0.185)\end{array}$ \\
\hline Nonmanufacturing & $\begin{array}{c}0.134 \\
(0.363)\end{array}$ & $\begin{array}{c}0.039 \\
(0.348)\end{array}$ & $\begin{array}{c}0.185 \\
(0.261)\end{array}$ & $\begin{array}{c}0.088 \\
(0.264)\end{array}$ & $\begin{array}{c}0.043 \\
(0.324)\end{array}$ & $\begin{array}{c}0.005 \\
(0.351)\end{array}$ \\
\hline Services & $\begin{array}{c}0.465 \\
(0.292)\end{array}$ & $\begin{array}{c}0.669^{*} \\
(0.339)\end{array}$ & $\begin{array}{c}0.935^{*} \\
(0.518)\end{array}$ & $\begin{array}{l}1.302 * * \\
(0.624)\end{array}$ & $\begin{array}{c}0.822^{*} \\
(0.557)\end{array}$ & $\begin{array}{l}1.170^{*} \\
(0.845)\end{array}$ \\
\hline Services $^{2}$ & $\begin{array}{c}-0.006^{* *} \\
(0.003)\end{array}$ & $\begin{array}{l}-0.009 * * \\
(0.003)\end{array}$ & $\begin{array}{c}-0.016^{* *} \\
(0.007)\end{array}$ & $\begin{array}{c}-0.022 * * \\
(0.009)\end{array}$ & $\begin{array}{c}-0.016 \\
(0.008)\end{array}$ & $\begin{array}{c}-0.020 \\
(0.011)\end{array}$ \\
\hline Ln GDP & & $\begin{array}{c}0.311 \\
(1.667)\end{array}$ & & $\begin{array}{c}1.012 \\
(1.447)\end{array}$ & & $\begin{array}{c}0.330 \\
(1.702)\end{array}$ \\
\hline Human & & 1.224 & & -0.990 & & -0.002 \\
\hline Capital & & (3.655) & & $(2.044)$ & & $(3.560)$ \\
\hline Government & & 0.073 & & 0.028 & & 0.067 \\
\hline Expenditure & & $(0.055)$ & & $(0.048)$ & & $(0.053)$ \\
\hline Trade & & $\begin{array}{c}0.011 \\
(0.020)\end{array}$ & & $\begin{array}{c}0.022^{*} \\
(0.011)\end{array}$ & & $\begin{array}{c}0.013 \\
(0.021)\end{array}$ \\
\hline Developed & & & $\begin{array}{r}-11.449 \\
(8.434)\end{array}$ & $\begin{array}{c}-9.886 \\
(9.566)\end{array}$ & & \\
\hline Developing & & & $\begin{array}{r}-12.153 \\
(9.437)\end{array}$ & $\begin{array}{c}-7.197 \\
(9.805)\end{array}$ & & \\
\hline Manufacturing $\times$ Developed & & & $\begin{array}{l}1.995 \\
(1.954)\end{array}$ & $\begin{array}{l}2.222 \\
(2.109)\end{array}$ & $\begin{array}{l}2.987 \\
(2351)\end{array}$ & $\begin{array}{c}3.414 \\
(3.107)\end{array}$ \\
\hline Manufacturing $^{2} \times$ Developed & & & $\begin{array}{c}-0.170 \\
(0.123)\end{array}$ & $\begin{array}{c}-0.191 \\
(0.125)\end{array}$ & $\begin{array}{c}-0.224^{*} \\
(0.159)\end{array}$ & $\begin{array}{c}-0.238 \\
(0.185)\end{array}$ \\
\hline Manufacturing $\times$ Developing & & & $\begin{array}{c}2.520 \\
(2.052)\end{array}$ & $\begin{array}{c}2.603 \\
(2.264)\end{array}$ & $\begin{array}{c}3.909 \\
(2.588)\end{array}$ & $\begin{array}{c}4.331 \\
(3.333)\end{array}$ \\
\hline Manufacturing $^{2} \times$ Developing & & & $\begin{array}{c}-0.190 \\
(0.127)\end{array}$ & $\begin{array}{c}-0.197 \\
(0.131)\end{array}$ & $\begin{array}{c}-0.260 \\
(0.168)\end{array}$ & $\begin{array}{c}-0.270 \\
(0.192)\end{array}$ \\
\hline Services $\times$ Developed & & & $\begin{array}{c}0.035 \\
(0.784)\end{array}$ & $\begin{array}{c}-0.014 \\
(0.925)\end{array}$ & $\begin{array}{c}-0.231 \\
(0.858)\end{array}$ & $\begin{array}{l}-0.376 \\
(1.265)\end{array}$ \\
\hline Services $^{2} \times$ Developed & & & $\begin{array}{c}0.006 \\
(0.010)\end{array}$ & $\begin{array}{c}0.007 \\
(0.012)\end{array}$ & $\begin{array}{c}0.009 \\
(0.011)\end{array}$ & $\begin{array}{c}0.010 \\
(0.016)\end{array}$ \\
\hline Services $\times$ Developing & & & $\begin{array}{c}0.069 \\
(0.796)\end{array}$ & $\begin{array}{l}-0.318 \\
(0.876)\end{array}$ & $\begin{array}{l}-0.080 \\
(0.860)\end{array}$ & $\begin{array}{l}-0.437 \\
(1.079)\end{array}$ \\
\hline Services $^{2} \times$ Developing & & & $\begin{array}{c}0.006 \\
(0.010)\end{array}$ & $\begin{array}{c}0.012 \\
(0.012)\end{array}$ & $\begin{array}{c}0.008 \\
(0.011)\end{array}$ & $\begin{array}{c}0.012 \\
(0.014)\end{array}$ \\
\hline Number of obs & 389 & 364 & 389 & 364 & 389 & 364 \\
\hline R-squared (overall) & 0.153 & 0.179 & 0.612 & 0.631 & 0.199 & 0.216 \\
\hline $\begin{array}{l}F \\
\text { Wald } \mathrm{chi}^{2}\end{array}$ & 3.838 & 3.197 & 363.830 & 481.440 & 5.579 & 6.211 \\
\hline
\end{tabular}

Notes: ${ }^{*}, *$ and ${ }^{* * *}$ : Significance at 10,5 and 1 per cent levels.

variables, nonmanufacturing, per capita income, human capital and government expenditure have no discernible effect on inequality. ${ }^{15}$ Trade has a positive and significant effect on inequality in the RE estimates (Col. IV), but not in the FE estimates.

Cols. (III) and (IV) display the results of the random effects regressions that aim to distinguish any difference in the marginal impact of manufacturing on inequality between different country groups. We find some evidence of heterogeneity in the effects of manufacturing employment share on inequality by country group, with the effect of manufacturing employment share on inequality being lower in structurally developing and developed countries as compared to structurally 
Table 3. Marginal effect of manufacturing and services employment share in FE II

\begin{tabular}{|c|c|c|c|}
\hline \multicolumn{2}{|c|}{ FE II - marginal effects of manufacturing } & \multicolumn{2}{|c|}{ FE II - marginal effects of services } \\
\hline Share of manufacturing & $\mathrm{d} y / \mathrm{d} x$ & Share of services & $\mathrm{d} y / \mathrm{d} x$ \\
\hline $1 \%$ & $-1.03 * *$ & $15 \%$ & 0.39 \\
\hline $5 \%$ & $-0.93 * *$ & $25 \%$ & 0.21 \\
\hline $10 \%$ & $-0.81 * *$ & $35 \%$ & 0.003 \\
\hline $15 \%$ & $-0.69 * * *$ & $45 \%$ & -0.15 \\
\hline $20 \%$ & $-0.57 * * *$ & $55 \%$ & $-0.34 * * *$ \\
\hline \multirow[t]{2}{*}{$25 \%$} & $-0.45 * * *$ & $65 \%$ & $-0.52 * * *$ \\
\hline & & $75 \%$ & $-0.70 * * *$ \\
\hline
\end{tabular}

Note: ${ }^{*}, * *, * *$ : Significance in $10,5,1$ per cent, respectively.

underdeveloped countries (though the interaction terms between manufacturing and services employment shares and country group dummies are not statistically significant at the 10 per cent level or below).

We present the marginal effect of manufacturing on inequality derived from Columns (III) and (IV) of Table 2 in Tables 3 and 4 at different levels of manufacturing employment share and by country groups. We find that the effect of manufacturing employment share on inequality is negative and statistically significant, irrespective of the level of manufacturing employment share (Table 3). Even when manufacturing employment share is close to the maximum of any period average between country groups ( 23 per cent), it still has a negative impact on inequality. This is a remarkable finding as it suggests that manufacturing-driven structural transformation will unambiguously decrease income inequality. Similarly, we find the effect of manufacturing employment share on inequality is negative and statistically significant for all country groups, for the relevant ranges of manufacturing employment share for each country group (Table 4).

We next turn to a discussion of the results on the effects of services-driven structural transformation on inequality in Tables 2, 3 and 4. In Table 2, we find that an increase in the share of employment in services unambiguously increases inequality across all specifications - the coefficients on the share of employment in services are positive and statistically significant at the 1 per cent level (Cols. I to VI). There is also a clear inverted U-shaped relationship between service employment share and inequality - the quadratic term on services is negative and significant in all specifications. This is also evident from Table 3, where the share of employment in services initially has a positive and significant effect on inequality, and then has a negative and significant effect, when the share goes past 45 per cent. We also obtain a similar finding when we disaggregate the results by country groups, with services-driven structural transformation first increasing inequality, then decreasing it, across all country groups (Table 4).

Table 4. Marginal effects by country groups in RE II

\begin{tabular}{|c|c|c|c|c|c|c|c|}
\hline \multicolumn{4}{|c|}{ RE II - marginal effects of manufacturing } & \multicolumn{4}{|c|}{ RE II - marginal effects of services } \\
\hline Manuf. share & Underdev. & Developing & Developed & Services share & Underdev. & Developing & Developed \\
\hline $1 \%$ & $-3.63^{* *}$ & -1.42 & $-1.79 * *$ & $15 \%$ & $0.66^{*}$ & $0.69 *$ & $0.85^{*}$ \\
\hline $5 \%$ & $-1.91 * *$ & -1.28 & $-1.60 * *$ & $25 \%$ & 0.23 & $0.50 *$ & $0.57 *$ \\
\hline $10 \%$ & 0.24 & $-1.1 * * *$ & $-1.36 * *$ & $35 \%$ & $-0.21 * * *$ & $0.31 *$ & 0.28 \\
\hline $15 \%$ & 2.39 & $-0.92 * *$ & $-1.12 * *$ & $45 \%$ & $-0.64 * * *$ & 0.12 & -0.01 \\
\hline $20 \%$ & 4.55 & -0.74 & $-0.88 * * *$ & $55 \%$ & $-1.07 * * *$ & -0.08 & $-0.30 * *$ \\
\hline \multirow[t]{2}{*}{$25 \%$} & 6.71 & -0.56 & $-0.64 * * *$ & $65 \%$ & $-1.50 * * *$ & -0.27 & $-0.59 * *$ \\
\hline & & & & $75 \%$ & $-1.93 * * *$ & -0.46 & $-0.87 * *$ \\
\hline
\end{tabular}

Note: ${ }^{*}, * *, * *$ : Significance in $10,5,1$ per cent, respectively. 
Table 5. Marginal effect of business services employment share

\begin{tabular}{|c|c|c|c|}
\hline \multicolumn{2}{|c|}{ Random effects } & \multicolumn{2}{|c|}{ Fixed effects estimates } \\
\hline Country group & $\mathrm{d} y / \mathrm{d} x$ & Country group & $\mathrm{d} y / \mathrm{d} x$ \\
\hline Underdeveloped & 3.90 & Underdeveloped & 2.74 \\
\hline Developing & $0.81^{*}$ & Developing & 0.20 \\
\hline Developed & $-0.67 * *$ & Developed & -0.72 \\
\hline
\end{tabular}

Note: ${ }^{*}, * *, * * *$ : Significance in $10,5,1$ per cent respectively in joint $F$-tests.

Overall, our results suggest if the Kuznets postulate were to hold, it does not do so for manufacturing but does so for services. We next undertake a series of tests to see if our results are robust to alternate specifications and estimation methods, which are reported in Supplementary Material S6. We find no change in our main findings.

What may explain the surprising result we get for services-driven structural transformation where it increases inequality initially, and then decreases it beyond a certain level of employment share in services? We had noted from Section 3 that a key growth sector in services as countries move from one stage of structural transformation to another was the business services sub-sector. We had also noted the large productivity difference between this sub-sector and other services sub-sectors. In order to examine whether business services has a different effect on inequality than non-business services, we estimate Equations (1) and (2), with the employment shares of business and non-business services entered separately in the same regression. In Table 5, we present the marginal effect of business services on inequality by country group (detailed results are available in Supplementary Material Table S4). In the random effects estimates, we find that the business services significantly increases inequality in the structurally developing countries, while decreasing it for structurally developed countries (with no discernible effect on structurally underdeveloped countries). This is in accord with our intuition that the growth of the business services sub-sector leads to increases in within-sector inequality increases in the services sector as workers in the business services sub-sector (mostly professionals working in banking, finance, and information technology) tend to be paid much better than workers in trade, restaurants and hotels, and other services sub-sectors (where a large proportion of employment is in the informal sector in the structurally underdeveloped and developing countries). However, for structurally developed countries, where productivity and income differences within services sub-sectors are not likely to be as high as in the other country groups, between-sector inequality starting dominating withinsector inequality in the overall behaviour of inequality as most workers in the economy are now employed in the services sector (leading to the downward movement in the between-group component of inequality, as captured in Figure 1).

\section{Conclusions}

Structural transformation is at the core of the process of economic development. While a rapid pace of structural transformation can lead to sustained economic growth, it can contribute to growing inequality, as had been suggested by Kuznets. In this paper, we examine whether structural transformation leads to higher inequality. We first document the very different paths of structural transformation that different countries have followed in the past five decades. Countries show different paths of structural transformation, being either structurally underdeveloped, structurally developing or structurally developed. We then investigate whether these different paths of structural transformation have had differential impacts on inequality, using a panel of developing and developed countries for the period 1960-2012. In contrast to the Kuznets hypothesis, we find that the movement of workers to manufacturing unambiguously decreases income inequality, irrespective of the stage of structural transformation that a particular country is in. However, in 
the case of services-driven structural transformation, we find that there is an inverted U-shaped curve between services employment share and inequality, with inequality first increasing with an increase in service employment share and then decreasing. We also find some evidence of heterogeneity in the impact of services-driven structural transformation on inequality, with inequality increasing in structural developing countries and decreasing in structurally developed countries. Thus, our findings suggest that the Kuznets postulate seems to apply more to services than to manufacturing-driven structural transformation.

A large literature has previously documented the beneficial effects that manufacturing-driven structural transformation can have on the economic development process through its positive effect on sustained economic growth and productive job creation (for example, Rodrik, 2013). In this paper, we establish another mechanism by which manufacturing can be beneficial to development employment creation in manufacturing can reduce overall inequality as well. This suggests a double dividend of manufacturing-driven structural transformation - through increased growth and reduced inequality. However, for the vast majority of low-income countries which would fall into the structurally underdeveloped category, there has been considerable debate on whether the prospects for a manufacturing-driven structural transformation is likely, given the twin forces of globalisation and labour-saving technological change (Rodrik, 2016; World Bank, 2017). For these countries, if the realistic possibility of structural transformation is the movement of workers from agriculture to services, our findings suggest that inequality may increase with further structural transformation.

\section{Acknowledgements}

We would like to acknowledge the helpful comments of the editor and two referees, as well as comments received from presentations in the ESRC GPID network, Australian National University, University of Queensland, University of Ghana, and Massey University.

\section{Disclosure statement}

No potential conflict of interest was reported by the authors.

\section{Notes}

1. A separate (and large) literature has looked at the validity of the so-called Kuznets curve -- the inverted Ushaped relationship between inequality and the level of per capita income - without finding an unambiguous support for the Kuznets curve hypothesis of inequality first increasing and then decreasing with economic development (for example, Anand \& Kanbur, 1993a, 1993b; Roine \& Waldenström, 2015). However, this literature has focused on the growthinequality relationship, while our interest in this paper is in the structural transformation-inequality relationship. One paper that looks at the effect of structural transformation on inequality is Angeles (2009). However, this paper does not differentiate between manufacturing- and services-driven structural transformation (by using total non-agricultural employment share as the core explanatory variable), which as we will show in this paper, have very different effects on inequality.

2. See https://www.rug.nl/ggdc/productivity/10-sector/.

3. See https://www.wider.unu.edu/project/wiid-world-income-inequality-database.

4. This exposition depends on the assumption that the inequality measures we are considering is decomposable. Among the inequality measures available in the literature, the variance of log income and mean log deviation (which is Theil's second index) has such decomposition properties - see Robinson (1976) and Kanbur (2017).

5. Several studies document the much higher productivity of manufacturing and services than agriculture in low-income countries (for example, Gollin et al., 2014).

6. It should also be noted that the assumption of low within-sector inequality that is being implicitly made of the agricultural sector in the Kuznets process may not be correct in many country contexts in Latin America, South Asia, and Sub-Sahara Africa, where the land distribution may be concentrated among a few land-owning elites.

7. We measure sectoral productivity as the ratio of real value added to total employment in the sector. The data are obtained from the GGDC database. 
8. This observation is also supported by the cross-country analysis undertaken by Duarte and Restuccia (2010) who show that productivity catch-up in industry explain about 50 per cent of the gains in aggregate productivity across countries, whereas low productivity in services and the lack of catch-up explain economic stagnation in low-income countries.

9. Nonmanufacturing comprises utilities, construction, and mining.

10. Since the Gini coefficient is bounded by zero from below and one from the top, one concern would be that Least Squares may not be an appropriate econometric strategy, given that the dependent variable is censored. However, as Figure S1 in the Supplementary Materials shows, most values of the Gini lie between 0.3 and 0.6 , with very few observations approaching zero or one.

11. Additional information on the control variables and the sources of data can be found in Supplementary Materials S3.

12. For example, countries with more favourable endowments of unskilled labour may have both larger manufacturing sectors as well as lower inequality (see Wood, 2017).

13. For example, a boom in global commodity prices may lead to a rise in employment in primary commodity sectors coinciding with an increase in inequality as incomes increase in high rent natural resource-intensive activities.

14. Descriptive statistics are presented in Supplementary Materials, Table S3.

15. We also added a quadratic term for nonmanufacturing as a robustness test, to see if adding the square of nonmanufacturing changes the finding on the lack of significance of the coefficient on nonmanufacturing employment share. When we do so, neither nonmanufacturing employment and its square are statistically significant.

16. These countries are Botswana, Ethiopia, Ghana, Malawi, Mauritius, Nigeria, Senegal, South Africa, Tanzania, Zambia, Egypt and Morocco in Africa, China, Hong Kong, India, Indonesia, Japan, Malaysia, Philippines, Singapore, South Korea, Taiwan, and Thailand in Asia, Argentina, Bolivia, Brazil, Chile, Colombia, Costa Rica, Mexico, Peru and Venezuela in Latin America, Denmark, Spain, France, Italy, Netherlands, Sweden, and the United Kingdom in Europe and the United States.

17. These countries are Burkina Faso, Cameroon, Kenya, Lesotho, Mozambique, Namibia, Rwanda and Uganda.

\section{ORCID}

Kunal Sen (D) http://orcid.org/0000-0001-5439-6619

\section{References}

Acemoglu, D., \& Robinson, J. A. (2002). The political economy of the Kuznets curve. Review of Development Economics, 6 , 83-2002.

Ackland, R., Dowrick, S., \& Freyens, B. (2013). Measuring global poverty: Why PPP matters. Review of Economics and Statistics, 95, 813-824.

Anand, S., \& Kanbur, S. R. (1993a). The Kuznets process and the inequality-Development relationship. Journal of Development Economics, 40, 25-52.

Anand, S., \& Kanbur, S. R. (1993b). Inequality and development A critique. Journal of Development Economics, 41, $19-43$.

Angeles, L. (2009). An alternative test of the Kuznets' hypothesis. Journal of Economic Inequality, 8(4), $463-473$.

Arndt, C., McKay, A., \& Tarp, F. (2016). Growth and poverty in Sub-Saharan Africa. Oxford: Oxford University Press.

Castello-Climent, A., \& Doménech, R. (2014). Human capital and income inequality: Some facts and some puzzles (BBVA Research Working Paper 12/28). Madrid, Spain: BBVA.

Comin, D., Lashkari, D., \& Mestieri, M. (2018). Structural change with long run income and price effects. Retrieved from http://www.dartmouth.edu/ d dcomin

Dabla-Norris, M. E., Kochhar, M. K., Suphaphiphat, M. N., Ricka, M. F., \& Tsounta, E. (2015). Causes and consequences of income inequality: A global perspective. Washington, DC: International Monetary Fund.

Diao, X., McMillan, M., \& Rodrik, D. (2017). The recent growth boom in developing economies: A structural change perspective (Working Paper 2313). Washington, DC: National Bureau of Economic Research.

Duarte, M., \& Restuccia, D. (2010). The role of structural transformation in aggregate productivity. The Quarterly Journal of Economics, 125, 129-173.

Feenstra, R., \& Hanson, G. (2003). Global production sharing and rising inequality: A survey of trade and wage. In E. K. Choi \& J. Harrigan (Eds.), Handbook of international trade (pp. 146-185). Malden, MA: Blackwell.

Galbraith, J. K., Halbach, B., Malinowska, A., Shams, A., \& Zhang, W. (2014). UTIP global inequality data-sets, 1963-2008: Updates, revisions and data checks (UTIP Working Paper no. 68). Austin: University of Texas.

Goldberg, P. K., \& Pavcnik, N. (2007). Distributional effects of globalization in developing countries. Journal of Economic Perspectives, 45, 39-82.

Gollin, D., Lagakos, D., \& Waugh, M. E. (2014). The agricultural productivity gap in developing countries. Quarterly Journal of Economics, 129, 939-993.

Haraguchi, N., Cheng, C. F. C., \& Smeets, E. (2017). The importance of manufacturing in economic development: Has this changed? World Development, 93, 293-315. 
Herrendorf, B., Rogerson, R., \& Valentinyi, Á. (2014). Growth and structural transformation. In P. Aghion \& S. Durlauf (Eds.), Handbook of economic growth (pp. 855-941). Amsterdam: Elsevier.

Kanbur, R. (2017). Structural transformation and income distribution: Kuznets and beyond (Working Paper no. 2017-01). Ithaca, NY: Charles H. Dyson School of Applied Economics and Management, Cornell University.

Krueger, A. O. (1978). Alternate trade strategies and employment in LDCs. American Economic Review, 68, $270-274$.

Krueger, A. O. (1980). Trade and employment in developing countries: Synthesis and conclusion. Chicago: University of Chicago Press.

Kuznets, S. (1955). Economic growth and income inequality. American Economic Review, 45, 1-28.

Kuznets, S., \& Murphy, J. T. (1966). Modern economic growth: Rate, structure, and spread (Vol. 2). New Haven: Yale University Press.

Lewis, W. A. (1954). Economic development with unlimited supplies of labour. The Manchester School, 22, $139-191$.

McMillan, M., Rodrik, D., \& Verduzco-Gallo, Í. (2014). Globalization, structural change, and productivity growth, with an update on Africa. World Development, 63, 11-32.

Mensah, E., Owusu, S., Foster-McGregor, N., \& Szirmai, A. (2018). Structural change, productivity growth and labour market turbulence in Africa (UNU-MERIT Working Paper No. 2018-025). Maastricht, The Netherlands: UNU-MERIT.

Riedel, J. (1988). Economic development in East Asia: Doing what comes naturally? In H. Hughes (Ed.), Achieving industrialisation in East Asia. (pp. 1-38). Cambridge: Cambridge University Press.

Robinson, S. (1976). A note on the U hypothesis relating income inequality and economic development. American Economic Review, 66, 437-440.

Rodrik, D. (2013). Unconditional convergence in manufacturing. Quarterly Journal of Economics, 128, 165-180.

Rodrik, D. (2016). Premature deindustrialization. Journal of Economic Growth, 21, 1-33.

Roine, J., \& Waldenström, D. (2015). Long-run trends in the distribution of income and wealth. In A. Atkinson (Ed.), The handbook of income distribution (pp. 469-592). San Diego: Elsevier.

Roope, L., Nino-Zarazua, M., \& Tarp, F. (2018). How polarized is the global income distribution? Economic Letters, 167, 86-89.

Sumner, A. (2017). The developer's dilemma: The inequality dynamics of structural transformation and inclusive growth (Working Paper No. 1). Global Poverty and Inequality Dynamics Research Network. Retrieved from https://www.gpidnet work.org/research/

Timmer, M. P., \& de Vries, G. J. (2009). Structural change and growth accelerations in Asia and Latin America: A new sectoral data set. Cliometrica, 3, 165-190.

Timmer, M. P., de Vries, G. J., \& de Vries, K. (2015). Patterns of structural change in developing countries. In J. Weiss \& M. Tribe (Eds.), Routledge handbook of industry and development (pp. 65-83). London: Routledge.

Wood, A. (1994). North-South trade, employment and inequality: Changing fortunes in a skill-driven world. Oxford: Clarendon Press.

Wood, A. (2017). Variation in structural change around the world, 1985-2015 (WIDER Working Paper 2017/34). Helsinki, Finland: UNU-WIDER.

World Bank. (2017). Trouble in the making? The future of manufacturing-led development. Washington, DC: Author. 


\section{Appendix}

Data:

The data on structural transformation come from the GGDC database of the University of Groningen (Timmer, de Vries, \& de Vries, 2015), with additional data from Mensah et al. (2018). The GGDC data is now widely used in the recent literature on structural transformation (see Diao et al., 2017; Comin et al., 2018). There are 40 countries in the GGDC database, which includes annual disaggregated data on real value added and employment by sector from 1960 onwards to 2010 in most cases, with data available for a few countries till 2012. For our purpose, the GGDC data provide data on manufacturing industry and non-manufacturing industry (construction, mining, and utilities) separately, as well as disaggregated data on services by type of sector (business services, government services, trade, hotels, restaurants, and so on). Table S1 in the Supplementary Material provides details of the 10 sectors in the GGDC data. Employment is defined as 'all persons employed', including all paid employees, as well as self-employed and family workers.

The GGDC dataset has 12 African countries (including North Africa), 9 Latin American countries, 11 Asian countries (including Japan) and the rest from Europe, and the United States. ${ }^{16}$ We supplement the data on African countries with that provided by Mensah et al. (2018), who use the identical methodology as in GGDC data for eight more low- and low-middle-income Sub-Saharan African countries. ${ }^{17}$ Together, these two sources of sectoral employment cover 80 per cent of Africa's GDP.

A key strength of the employment data is that the source of the data is the population census, which ensures full coverage of the working population as well as a precise sectoral breakdown. The population census which tends to be quinquennial or decennial in most countries is supplemented by the labour force surveys and the business surveys to derive annual trends. The use of the population census also ensures that informal employment, which is important in many low and middle-income countries, is captured in the GGDC data. A feature of the data is the careful attention paid to intertemporal, international, and internal consistency (Diao et al., 2017; Timmer \& de Vries, 2009). This differentiates the quality of the data from other sources of employment data, such as the International Labour Organisation's ILOSTAT, which compiles data directly obtained from country sources without the consistency checks undertaken by GGDC (see Section S2 in Supplementary Materials).

Table A1. Stages of structural transformation

\begin{tabular}{lll}
\hline $\begin{array}{l}\text { Structurally underdeveloped } \\
(13 \text { countries })\end{array}$ & $\begin{array}{c}\text { Structurally developing } \\
(16 \text { countries })\end{array}$ & $\begin{array}{c}\text { Structurally developed } \\
(19 \text { countries })\end{array}$ \\
\hline $\begin{array}{lll}\text { Burkina Faso } \\
\text { Cameroon }\end{array}$ & Bolivia & Argentina \\
Ethiopia & Brazil & Chile \\
India & Botswana & Denmark \\
Kenya & China & France \\
Malawi & Colombia & Hong Kong \\
Mozambique & Costa Rica & Italy \\
Nigeria & Egypt & Japan \\
Rwanda & Ghana & Malaysia \\
Senegal & Indonesia & Mauritius \\
Tanzania & Lesotho & Mexico \\
Uganda & Morocco & Netherlands \\
Zambia & Namibia & Singapore \\
& Peru & South Korea \\
& Philippines & Spain \\
& Thailand & Sweden \\
& South Africa & Taiwan \\
& & United Kingdom \\
& & United States \\
\hline
\end{tabular}

Note: Structurally underdeveloped: share of employment in agriculture higher than in manufacturing or services; structurally developing: share of employment in services higher than in agriculture; structurally developed: share of employment in manufacturing higher than in agriculture. 